\title{
LEGAL CULTURE ON JUSTICE AND TRUTH: THE TRIBUNALS OF INQUIRY ABOUT BLOODY SUNDAY
}

\author{
JOSEFA-DOLORES RUIZ-RESA ${ }^{1}$
}

\begin{abstract}
Almost 50 years ago, in the events that happened during the so-called Bloody Sunday (Derry $1972,30^{\text {th }}$ January), 13 Catholic civilians were killed because of the actions of the British army during a civil rights march against internment without trial in Northern Ireland. Other 13 civilians were injured. While the circumstances were unclear, these civilians were considered to be terrorists, which seemed to justify the gunfire. The findings on Bloody Sunday from two Tribunals of Inquiry (1972 and 1998-2010), and the reactions that their resulting reports raised are an excellent example of cultural impregnation in law. In this regard, it is possible to find a general notion of justice as truth. Guaranteeing such notion (or, at least, the willingness to ensure it) seemed to facilitate the peace process in Northern Ireland. Under the light of these events, the following pages aim to analyse how that legal culture of justice as truth is displayed in the two Bloody Sunday Tribunals of Inquiry as well as its contribution to the contestation of the British legal system or its legitimacy. This paper starts by reviewing previous studies about the conceptual framework of the analysis - it examines the concept of "legal culture" and the understanding of justice as truth, as well as the definition of Tribunal of Inquiry. Next, it argues cultural perceptions regarding Bloody Sunday Inquiries. The conclusions exposed reveal that the legal culture of justice as truth is also embodied in legalism and colonialism.
\end{abstract}

Keywords: Legal Culture, Bloody Sunday, Tribunal of Inquiry, Justice, Truth, Legalism, Colonialism, Legitimacy.

Summary: 1. Introduction. 2. Conceptual frame. 2.1. Legal culture. 2.2. Truth as part of justice. 2.3. The Tribunal of Inquiry as part of public inquiries. 3. Legal CULTURE AND BloOdy Sunday TRIBUnALs of InQUiRY. 3.1. Context. 3.2. Trauma, anger and disappointment: Legal culture on Widgery inquiries during the 70s and 80s. 3.3. To set the truth: the Justice Campaign and other expressions of legal culture during the 1990s. 3.4 Legal culture on the Saville Tribunal and Report: legalism, colonialism and new legitimation for British law. CONCLUSION

\section{INTRODUCTION}

Margo Harkin's documentary 'Bloody Sunday - A Derry Diary' (final version, $2010)^{2}$ has a scene where a large crowd in front of the Guildhall in Derry - the symbol of the Unionist domination - is watching Prime Minister David Cameron on an enormous TV screen ${ }^{3}$. He is addressing the House of Commons, reading his statement on the day

\footnotetext{
${ }^{1}$ Facultad de Derecho, Universidad de Granada, Spain (jruizr@ugr.es).

2 Benson Productions. Available from: http://www.besomproductions.co.uk/sunday.html [retrieved 20/02/2020]

${ }^{3}$ Available on https://www.youtube.com/watch?v=KCsIg817Xa8 [retrieved 20/02/2020]
} 
when the report of the second Bloody Sunday Tribunal of Inquiry, chaired by Lord Saville, was published. Bloody Sunday is the name given to the events that happened on $30^{\text {th }}$ January 1972, when the British army killed 13 people and injured other 13 during a civil rights march in Derry (Londonderry, according to its British official name). It was a march against internment without trial in Northern Ireland. The march and the shootings happened in the contexts of the conflicts called The Troubles. Nonetheless, the report of the first Tribunal of Inquiry, chaired by Lord Widgery, sowed the suspicion that the killed and wounded people were terrorists, which explained the soldiers' action as legitimate and justified the soldiers' shootings.

In his speech, Mr Cameron states (2010):

'(...) Mr Speaker, I am deeply patriotic. I never want to believe anything bad about our country. I never want to call into question the behaviour of our soldiers and our army, who I believe to be the finest in the world.

And I have seen for myself the very difficult and dangerous circumstances in which we ask our soldiers to serve.

But the conclusions of this report are absolutely clear. There is no doubt, there is nothing equivocal, there are no ambiguities. What happened on Bloody Sunday was both unjustified and unjustifiable. It was wrong (...) The government is automatically responsible for the conduct of the army forces and for that, on behalf of the government, indeed on behalf of the country, I am deeply sorry'.

Suddenly, the audience watching the TV in the streets cheered and applauded.

As mentioned above, the Saville report was the result of the findings made by a second Tribunal of Inquiry about Bloody Sunday. It is considered that the setting up of this tribunal in 1998 led to the Agreement of Belfast, also known as the Good Friday Agreement. A peace process between Northern Ireland and the British State just commenced.

The goal of a Tribunal of Inquiry is not the judgments of guilt or innocence, but to find the truth about those situations or events that alarm people. However, the following and final scenes of the documentary show the victims' families acquitting the victims themselves, as if they were judges, making the streets become a Court, proclaiming the final judgment of "innocence". Thus, what ordinary people consider justice to be seems very different from what the law enacts. This proves that there is a "popular" sense of justice and a social culture of the legal and the fair. It is clear that since the second decade of $20^{\text {th }}$ century, civil rights have included a collective dimension. This dimension links the idea of justice to the representations not only of the official or state legal culture but also the popular legal culture. This legal culture can be clearly observed in the Bloody Sunday's events, with special emphasis on its inquiries, which are also progressively reverberating and being supported within films, poetry, pieces of theatre or TV documentaries, like Harkin's. 
The specific events that triggered Bloody Sunday revealed a background of increasing political tension and violence in Northern Ireland that started in 1968, when the protest against the situation spread out, leading to civilians being killed by the British Army as riots intensified. Many people were arrested and taken to camps at that time. It was a measure adopted by the Unionist Government of Northern Ireland (the Stormont government) on 9 August 1971, and the British Government supported it. According to British Irish Rights Watch (1994, paragraph 2.2), "by the end of 1971 around 900 people, virtually all of them nationalists, were imprisoned, in violation of international norms on the right to a fair trial". Thus, internment must be understood within the framework of The Troubles (the Northern Ireland political conflict), as this region continued to be part of the United Kingdom but not of the Republic of Ireland. On the other hand, the Troubles must be understood within the widespread political and social discrimination against Catholics in Northern Ireland for centuries ${ }^{4}$.

The anti-internment protests brought more riots and violence, more civilians shot dead by the British Army or taken away for internment, as well as British soldiers, officers and other civilians shot dead by the Irish Republican Army (IRA). Finally, on $10^{\text {th }}$ January 1972, the Prime Minister of Northern Ireland, Brian Faulkner, banned all marches in Northern Ireland until the end of the year. However, an anti-internment march was organized by the Northern Ireland Civil Rights Association (NICRA), leading to the specific episode that is the object of this paper.

The members of the NICRA had organized a march in Derry to protest against internment without trial in Northern Ireland. In Derry, Catholics lived in the districts of Creggan and the Bogside, which were republican no-go areas (they were called Free Derry). This place was under the effective control of the Irish Republic Army (IRA), which was considered to be a terrorist organization. It is no wonder that British Security Forces were unhappy with this and that the Commander Land Forces in Northern Ireland, General Ford, had ordered his troops "to recreate the state of law in the Creggan and Bogside" (British Iris Rights Watch 1994: 2.3).

The march was allowed to proceed in the Catholic areas. However, it should not reach the Guildhall Square, as the organizers had planned. Meanwhile, General Ford ordered the $1^{\text {st }}$ Battalion Parachute Regiment ( $1^{\text {st }}$ Paras $)$ - the toughest regiment in the army - to travel to Derry to arrest rioters. Thousands of people took to the streets. The march went peacefully until it arrived at the junction of William Street and Roseville Street. A barrier in William Street prevented protesters from venturing beyond it. At least 26 barriers surrounded the Creggan and Bogside to cordon them off from the rest of the city. Nonetheless, about 200 marchers broke away from the procession and started to throw stones at the soldiers, turning the march into an "illegal demonstration" (British Irish Rights Watch, 1994, p. 2). The soldiers fired rubber bullets and water cannon in return, and the Parachute Regiment started the arrest operation. In only a few minutes, the troops began the shooting that resulted in 13 civilians killed (most of them were young

${ }^{4}$ A more comprehensive study about this can be found in Neumann, 2003. 
men and even teenagers $)^{5}$ and 13 injured $^{6}$. Among the wounded, there was one person who passed away from a brain tumour not long after the event. Given that the trauma was thought to have contributed to the decease of this individual, his death was acknowledged as the $14^{\text {th }}$ of Bloody Sunday ${ }^{7}$. None of the soldiers involved in the firing was killed nor slightly injured (British Irish Rights Watch, pp. 6, 7).

A Tribunal of Inquiry was immediately set up after the events, and the Lord Chief Justice of England, Lord Widgery, was appointed chairman. Having the Lord Chief Justice handling this responsibility (that is, the head of Judiciary of England and Wales and the President of the Courts of England and Wales $)^{8}$ revealed that the British Government was taking the matter very seriously. Nevertheless, some Members of Parliament had doubts about him being the sole member of the Tribunal. The Widgery Tribunal did its work in a few months, and the final report was delivered $10^{\text {th }}$ April with less than 100 pages.

The immediate inquiries, collected in the Widgery Report, exposed that "none of the deceased or wounded is proved to have been shot whilst handling a firearm or bomb" (Report of the Tribunal 1972), while the conclusions in the Report stated that the soldiers were not the first to open fire, meaning that they were not responsible for the victims. On the other hand, it concluded that, although some of the dead were "wholly acquitted of complicity in [handling a firearm or bomb], (...) there is a strong suspicion that some others had been firing weapons or handling bombs"

Relatives saw this as an offence against the victims because it implicitly entailed the fact that they were considered terrorists. However, photographs and eyewitnesses revealed that nobody was armed. In order to understand the families' sorrow, it is necessary to take into account that new details came to light later on ${ }^{10}$, such as, the case of 22-year-old James Wray, who was killed while lying wounded; the fact that William McKinney was killed when he was bending towards an injured person and that Bernard McGuigan was killed when he tried to assist a wounded man, even though he was waving a white handkerchief in his hand. During the following years after the end of the Widgery Tribunal, new evidence brought out the troops' actions, revealing that they might have shot at unarmed people, as

\footnotetext{
${ }^{5}$ They were 17-year-old Gerard Donaghy, Michael Kelly, Kevin McElhinney, Jack Duddy and Hugh Gilmore, 19-year-old William Nash, 20-year-old Michael McDaid, 22-year-old James Wray, 26-year-old William McKinney, 31-year-old Patrick Doherty, 35-year-old Gerard McKinney and 41-year-old Bernard McGuigan.

${ }^{6}$ John Johnson, Damien Donaghy, Michael Bridge, Michael Quinn, Patrick O’Donnell, Patrick McDaid, Alexander Nash, Margaret Deer, Michael Bradley, Patrick Campbell, Joseph Friel, and Daniel McGowan.

${ }^{7}$ John Johnson.

${ }^{8}$ The equivalent concept in Spain would be the President of the Supreme Court and Consejo General del Poder Judicial.

${ }^{9}$ According to the conclusions of the Report (1972), “10. None of the deceased or wounded is proved to have been shot whilst handling a firearm or bomb. Some are wholly acquitted of complicity in such action. However, there is a strong suspicion that some others had been firing weapons or handling bombs in the course of the afternoon and that yet others had been closely supporting them".

${ }^{10}$ It is important to consider the investigations managed by civil rights associations, journalists, eyewitness and families. These investigations will be addressed later.
} 
well as that 3 victims were shot from the walls and not from the ground, which indicated that the soldiers did not open fire as a defensive action against armed demonstrators ${ }^{11}$.

On the other hand, the use of terms like "acquitted" or "found not guilty" made people think that Widgery Tribunal ended up becoming a sort of trial of the victims, based on the adversarial system, rather than a Tribunal of Inquiry that is supposed to search for the truth from an inquisitorial approach. According to Walsh (1997), certain elements led to this result: "it was chaired by the Lord Chief Justice, it identified two adversarial protagonists... it left the presentation of evidence largely to these two parties, it conducted its proceeding along the lines of an adversarial trial and it delivered its report in a judicial style which found in favour of one party or the another on most issues".

In any case, victims, families and many other people would have preferred criminal charges against the shooters, but the evidence to warrant the criminal prosecution were considered insufficient ${ }^{12}$. On the other hand, the adversarial procedure did not seem a solid guarantee either, since it led to significant mistakes associated to other well-known cases likewise related to The Troubles, like the Guilford Four and Birmingham Six. This very situation brought about important reforms to the adversarial procedures in England and Wales during the last years of the $20^{\text {th }}$ century, as Van Koppen and Penrod $(2003$, p. 1) point out. Many of these reforms concerned the guarantee for the right to a fair trial and, especially, the right to be heard by a competent, independent and impartial tribunal. Trials seemed as biased as the Widgery Tribunal, which took the army's side instead of acting as arbitrator.

Bearing this context in mind, the following pages aim to illustrate how the legal culture of justice connects justice to truth and how that connection impacts on the legitimacy of the states and their legal systems. In order to do so, this paper will analyse the events regarding the Bloody Sunday Tribunals of Inquiry. They are a paradigmatic example of how law, justice and legal culture are interconnected. The paper will also analyse the importance of truth as main content of justice in order to achieve a more legitimate social, political and legal system from a practical point of view ${ }^{13}$. The analysis will allow to come to the conclusion that justice and truth also interact with legalism and colonialism, which are likewise part of the legal culture. However, they demean in some way the victims and families' claims and the peace process in Northern Ireland.

The structure of the article goes as follows: after revising the studies about the conceptual framework of analyses - the notion of legal culture and justice as truth, as well

\footnotetext{
${ }^{11}$ See Circumstances in which people were killed, available at https://cain.ulster.ac.uk/events/bsunday/ circum.htm

${ }^{12}$ The civil action for damages, the victims' families received a modest payment because the victims were found not guilty of being shot while handling a firearm or a bomb. To know more about the judicial review of the event of Bloody Sunday, including the remedies from the International Law and their little success, see Walsh 2000, p. 284-313.

${ }^{13}$ As it is well known, the importance of social acceptance of law to enforce it was pointed out by Legal Realism (Ross, Olivecrona, Holmes, Pound, Frank).
} 
as the definition of Tribunal of Inquiry - an analysis of the cultural perception about the Tribunals of Inquiries is introduced along with an evaluation of how legal culture dealt with the Bloody Sunday Inquiries.

The methodology of the article is based on the analysis of texts from different scholars addressing the concepts (legal culture, justice as truth) that will be applied to the analysis of documents that are related to Bloody Sunday Tribunals of Inquiry and to the presence of legal culture within them ${ }^{14}$. The analysis will not be performed from the scope of cultural theory, media studies, visual arts or social memory studies. Instead, it will be based on legal philosophy, insofar as it is linked to its standard sections: the theory of law (assuming that law includes not only norms and institutions but also a cultural component), the methodology of legal knowledge (agreeing that the search for the truth is an intrinsic principle within the theory of procedure), and the theory of justice (considering truth as part of justice and political accountability within democracies). All three will provide a broader debate for connecting the theory of human rights to the fields of legal Epistemology, Ontology and Ethics ${ }^{15}$.

\section{CONCEPTUAL FRAMe}

\subsection{Legal culture}

The idea of legal culture was mainly developed by Lawrence Friedman (1969, 1977), who inspired the Law \& Society Movement. He defended a social theory of law and considered that law was made up of three kinds of components: substantive, structural and cultural. More specifically, Friedman (1969, p. 34) explains that ${ }^{16}$ :

"A working legal system can be analyzed further into three kinds of components. Some are structural. The institutions themselves, the forms they take, the processes that they perform: these are structure. Structure includes the number and types of courts, presence or absence of a constitution, presence or absence of federalism or pluralism, division of powers between judges, legislators, governors, kings, juries, administrative officers; modes of procedure in various institutions, and the like. Other components are substantive. This is the output side of the legal system.

\footnotetext{
${ }^{14}$ Many of these documents are classified and available on CAIN (Conflict Archive on the Internet, located at the University of Ulster) Web Site https://cain.ulster.ac.uk/index.html, especially at https://cain.ulster. ac.uk/cgi-bin/dbase.pl. The bibliography consulted is temporarily related to the years between the two Inquiries (1972-2010), especially, as well as to the echo that the second Report had on public opinion and scholars during the following five or six years, which currently seems to be weakened. The forthcoming $50^{\text {th }}$ anniversary is likely to make new studies arise.

${ }^{15}$ Those are considered the three fields within the Legal Philosophy. See Legaz y Lacambra, 1953, p. 30-34; Bobbio, 1980, p. 91-101; Salguero, 2014, p. 192-199.

${ }^{16}$ This extended quotation is included in the present paper because Friedman uses a list of situations, procedures, kind of people and set of prescriptive and descriptive statements in order to define the three components.
} 
These are the laws themselves -the rules, doctrines, statutes and decrees, to the extent they are actually used by the rulers and the ruled; and, in addition, all other rules and decisions which govern, whatever their formal status. Other elements in the system are cultural. These are the values and attitudes which bind the system together, and which determine the place of the legal system in the culture of the society as a whole. What kind of training and habits do the lawyers and judges have? What do people think of law? Do groups or individuals willingly go to court? For what purposes do people turn to lawyers; for what purposes do they make use of other officials and intermediaries? Is there respect for law, government, tradition? What is the relationship between class structure and the use or non use of legal institutions? What informal social controls exist in addition to or in place of formal ones? Who prefers which kind of control, and why? ${ }^{17}$

These aspects of law -the legal culture-, influence all of the legal system. But they are particularly important, as the source of demands made on the system. It is the legal culture, that is, the network of values and attitudes relating to law, which determines when and why and where people turn to law or government, or turn away (...) The living law of a society, its legal system in this revised sense (...) is the way in which structural, cultural and substantive elements interact".

Friedman also distinguished between internal legal culture, which refers to the knowledge degree of legal practitioners on law and external legal culture, or the knowledge degree of people who are not lawyers. The distinctions between one type of culture and another have sparked to some controversy, just like the various meanings Friedman assigned to this term in the second half of the $20^{\text {th }}$ century. And yet, he admitted in later works that external legal culture is equivalent to legal consciousness, as it identifies with the opinions, values and expectations that ordinary citizens hold regarding the legal system. Although it may seem obvious that lawyers have a different - and, apparently, isolated - view on law and themselves as compared to ordinary people (for they receive a specialised education), it is not possible to draw a clear distinction between internal and external legal cultures. Thus, when jurists are learning and use internal legal culture, it should not be inferred that all vestiges of external or popular culture are eliminated. The reason why this happens is that the interpretation of texts (including legal ones) is seen as the way of bringing the meaning of the texts to the fore and updating it, which occurs when interpreters translate the texts following the culture at that time. Gadamer (1977) highlighted this point when he said that the interpreters of a legal text are not limited to reproducing it; instead, they adapt it to their own historical time and social values.

Apart from the distinction of external and internal legal culture, Friedman (1989, p. 1578-1579) ${ }^{18}$ distinguishes between legal culture and popular legal culture. By "legal culture" he means "ideas, attitudes, values and opinions about law held by people in

\footnotetext{
${ }^{17}$ Also in Friedman, 1977, p. 6 and 7.

${ }^{18} \mathrm{He}$ referred to it in similar words in Friedman, 1969 and 1994.
} 
society". Popular legal culture would mean, on the one hand, law-related ideas and attitudes held by ordinary people or, more generally speaking, by laypeople. In other words, it takes into account the opinion and attitude of ordinary people towards the substantive and structural components involved in legal systems. On the other hand, popular legal culture refers to "books, songs, movies, plays and TV shows (...) about law or lawyers and aimed at a general audience".

Many studies have shown that modern "ordinary people" know very little about the law and legal systems. On many occasions, TV programs and movies become law educators. Nowadays, TV trials are one of the most important tools for ordinary people's legal education. Trials are, according to Friedman (1989, p. 1594), "boundary-maintaining devices" and help to "cement social solidarity by redefining and proclaiming the norm". Following Vygotskii's ideas on the intermediation of culture in our cognition (2010), Jerome Bruner $(1990,1996)$ highlighted how culture takes part in it and how school education and learning is a way of internalising cultural norms and values. Bruner then pointed out how the law, as part of the culture, contributes to education through the legal narrative, including the stories that norms and case law narrate about political institutions, people out or within the law and also out or within societies (2003). Indeed, a significant number of the most recalled films or TV series - one of the most important cultural expressions - deal with trials. Examples include the well-known films Twelve angry men, directed by Lumet; Judgment at Nuremberg, by Kramer; or Witness for the Prosecution, by Wilder; and also have musicals like Chicago (Ebb, Fosse \& Kander). In any case, trials have been and still are a kind of theatrical or ritualized display of law.

Friedman emphasized how the three components - structural, substantive and cultural-influence each other, and how, ultimately, the effectiveness of laws depends on the legal culture, both internal (that of practitioners and law theorists) and external or popular (the rest of the citizens). Every meaning or dimension of the legal system rests, as Friedman affirmed (1989, p. 1589), on sociocultural norms: habits, stereotypes, costumes, morality. Either implicitly or explicitly, these norms are part of the components - structural, substantive or cultural — of every legal system. They also function as both unwritten and unconscious norms that bring cohesion in our societies and govern them (Aristodemou, 2014, p. 5).

In any case, the concept of legal culture should be regarded under the influence of the debate concerning the contradictory theoretical approaches to the concept of culture. There are, indeed, other conceptions of law rooted in - or involving - more metaphysical understandings of culture, such as those based on modern German philosophers like Herder, Fichte ${ }^{19}$, or postmodernist conservative ones ${ }^{20}$. Considering that modern law is connected to the development of modern nation-states, the fact that legal cultures are also seen as expressions and tools for the spread of national cultures is not surprising.

\footnotetext{
${ }^{19}$ About the conception of culture within them, see Bueno, 2000

${ }^{20}$ See Gilroy 1995.
} 
On the other hand, a map can be drawn out of the conceptions of "culture" and "popular culture", according to Storey (2018). First, "popular culture" seems to be defined from the contrasts or connections to other theoretical categories such as folk culture, mass culture, high culture, working-class culture. Second, it should be noted that the definition of culture itself is also very complicated and discussed. As to Raymond Williams (1983) put it, the term in English would mean "a general process of intellectual, spiritual and aesthetic development", "a particular way of life, whether a people, a period or a group", and "the works and practices of intellectual and especially artistic activity" ${ }^{21}$ - texts and practices that produce meanings. "Popular culture" would, therefore, be associated to the second and third meanings of culture, according to which, the concept of popular culture includes Christmas celebrations and youth subculture, as well as soap operas, comics and pop music.

Third, the term "culture" is traditionally close to "ideology" and at times even interchangeable. This closeness allows "culture" and "popular culture" to approach certain meanings provided by Marxism, such as masking the distortion of reality by producing false consciousness and particular images of the world chosen by one of the sides in a social conflict. Consequently, this would mean that all texts are somehow political. As Barthe's work explains, "ideology" can be seen, as a producer or bearer of connotationssecondary unconscious meaning, including general words like "man" that would express the normal, the natural, the universal, in contrast to other human beings. Nevertheless taking Althusser's approach, "ideology" could refer not only ideas but also material practices. Keeping in mind the thoughts above, the concept of "popular culture" is much more than entertainment or leisure. It also implies political and social struggle (Storey, 2018).

Fourth, "popular culture" is usually a complex combination of various meanings, according to Williams: "well-liked by many people", "inferior kinds of work", "work deliberately setting out to win favour with the people", and "culture made by the people for themselves"22. All possible combinations lead to different definitions of "popular culture": that which is imported (typically from the USA) and opposed to culture as something coming from a lost or ideal folk or organic community, and that which is not high culture considered as difficult. This assumption results in oppositions such as popular press vs. quality press, popular cinema vs. art cinema, popular entertainment vs. art. A different combination leads to consider "popular culture" as "mass culture"-a mass-produced and mass-consumed culture - and "commercial culture" (Storey 2018).

Finally, there is the conception of "popular culture" linked to the idea of hegemony (according to Gramsci), which reflects the political and social struggles between dominant and subordinate groups [which in turn can be understood as cultural minorities or groups, according to, for example, the theories of justice as recognition]. The former would try to assimilate the latter into their ideas and world organization, while the latter would try to resist. Therefore, "popular culture" is not a mass commercial culture, but a culture of spontaneous opposition by the people constituting the subordinate groups (Storey, 2018).

\footnotetext{
${ }^{21}$ Quoted in Storey, 2018.

${ }^{22}$ Quoted in Storey, 2018.
} 
As a result, it is inevitable to accept a dynamic notion of culture, based on its meanings and samples (texts, practices, technologies, objects), but also on its producers: individual human beings gathered in social, political, legal and historical changing groups. This is where complex shifting power relations can occur, and they can shift through struggles and negotiations between groups and individuals within those groups.

From this wide range of interpretations, one may derive certain assumptions that could refine the categories of legal culture and popular legal culture. Thus, regarding high legal culture as high culture in terms of difficulty and rationality, as well as quality and minority — since it is available to very few people_- high legal culture might be including legal scholars' works and practitioners' writings. This should also be regarded as internal legal culture (in the sense of "lawyerly" produced or produced by lawyers). Within the understanding of high legal culture, other manifestations of what is considered high culture can be added, like some forms of art and literature - poetry, theatre, novels, picture, sculpture, classical music, and even art cinema or jazz music. However, those would also involve external legal culture ("not lawyerly" produced or not produced by lawyers).

On the other hand, popular legal culture would include forms of culture that are currently considered simpler, like products without intellectual quality. Today these can be texts and other works like comics, murals, pop music - and its different styles including rock or rap-, soap-operas and other forms of culture represented through the mass media (television, press). These cultural manifestations can respond to mass and commercial culture to a certain extent, meaning quantity over quality, and they can also portray an idea of the law as a kind of resistance against the dominant legal culture and its ideas of law (traditionally supported and guarded by legal operators who are specifically trained). Under the light of this meaning, popular legal culture can also include demonstrations, marches, memorials, tributes and many other actions that can be contemplated as articulated or spontaneous political activism.

The meaning of high and popular legal culture could change if society changes what is historically and dialectically considered to be intellectually difficult. On this basis, the numerous studies available on law and literature include works that range from those contemplated within the Western canon ${ }^{23}$, such as The Merchant of Venice, by Shakespeare, to the comics about Daredevil, a blind lawyer who became a Marvel hero thanks to Stan Lee and Bill Everett. Similar remarks can be made regarding law and film studies.

\subsection{Truth as part of justice}

Seeing truth as a fundamental content of justice is a regular debate within the theory of justice, but also within the theory of legal procedure and social and political theory. In all these fields, truth is considered to be a vital value in justice, as it is well

\footnotetext{
${ }^{23}$ See Pérez 2006. About the western canon literature, see Bloom, 1995.
} 
noticed by Michele Taruffo (2010, pp. 114-153). From the legal point of view, Taruffo (2010, pp. 135-136) stresses that the procedure will not work by taking into account only the formal aspects because a fair resolution of a case implies an accurate determination of the facts. Moreover, determining the truth of the facts through dynamic behaviour is the way for judges to be neutral or impartial. On the other hand, Taruffo (2010, pp. 138-140) reminds us that justice as truth is a principal social value, because the truth is ethics as opposed to lies, as many moral philosophers like Aquino or Kant pointed out. More recently, other philosophers like B. Williams and M. P. Lynch have highlighted that truth matters as a necessary tool for social life (Taruffo, 2010, pp. 110-111). According to language and communication researchers like Paul Grice, the main principle within social communication is truth. Truth is necessary within the relations between a democratic state and its citizens, unlike dictatorships, totalitarian regimes and any sort of tyrant systems, where lies are the standard common tool (2010, pp. 111-114).

Furthermore, truth is an essential and traditional goal in inquisitorial legal procedures in order to ensure that there is no impunity but accountability. Relying on the judge's control, it is typical within civil law systems. Adversarial legal procedures are rather based on the conflicting evidence and points of view of the parties, where the judge acts as an arbitrator-it is typically seen in Common Law systems (Van Koppen and Penrod, 2003). In this context, truth is linked to persuasion and is mainly the result of negotiation or transition between the parties. Therefore, it involves giving equal value to different views on the actual events.

On the other hand, truth is the first step towards achieving reparation, and guarantees non-recurrence, which also needs to be remembered, mourned and retrieved as part of a so-called social or historical memory. As it is known, in September 2011, the Special Rapporteur on the promotion of truth, justice, reparation and guarantees of non-recurrence was appointed by the United Nations Human Rights Council (resolution 8/11). A task requested by the Council to this Special Rapporteur is "[t]o gather relevant information on national situations, including on normative frameworks, national practices and experiences, such as truth and reconciliation commissions and other mechanisms, relating to the promotion of truth, justice, reparation and guarantees of non-recurrence in addressing gross violations of human rights and serious violations of international humanitarian law (...)"24. Undoubtedly, truth and justice have also become deeply connected today from the perspective of international legal institutions.

Currently, all these contents are also essential within transitional justice, considered to be "the conception of justice associated with periods of political change, characterized by legal responses to confront the wrongdoings of repressive predecessor regimes", as Teitel (2003, p. 69) points out. According to her (2003), there are three different phases within transitional justice: the post-war phase, which goes from 1945 to

\footnotetext{
${ }^{24}$ See The Mandate of the Special Rapporteur on the promotion of truth, justice, reparation and guarantees of non-recurrence, available on https://www.ohchr.org/EN/Issues/TruthJusticeReparation/Pages/Mandate. aspx. Last retrieved 19/02/2020).
} 
the end of the Cold War, is symbolized by Nuremberg Trials; the second phase or postCold War phase, which lasts to the last years of the $20^{\text {th }}$ century, is focused on the truth commission rather than on trials; and the third phase or current phase, where transitional justice is extended and generalized. "A truth commission is", according to Teitel (2003, p. 78), "an official body often created by a national government to investigate, document and report upon human rights abuses within a country over a specific period of time". Although not part of the criminal justice systems or the judiciary, transitional justice entails a formal legal state initiative that also involves informal forms of dialogue and negotiation between victims and perpetrators. According to Teitel, truth is juxtaposed to justice during the second phase, but truth commissions already existed but were called by different names, such as "Tribunal of Inquiry" in Great Britain. This second phase includes the human rights vocabulary and claims the rights to the truth as opposed to the duty of States to guarantee them. In any case, Teitel (2003, p. 81) emphasizes the idea that there are conflicting relations among truth, justice and memory.

In any event, it is possible nowadays to state that the right to the truth and its connection to the idea of justice are part of international human rights soft law. According to the Report of the Office of the United Nations High Commissioner for Human Rights (2006) ${ }^{25}$, the concept of this right roots in international humanitarian law (para. 5) and the current legal basis for the right to truth and the state duties related to it can be found within several legal documents, like for example (para. 4), the principles 2 (the inalienable right to the truth), 4 (the victims' right to know) and 1 (General obligations of states to take effective action to combat impunity) set forth in The updated Set of principles for the protection and promotion of human rights through action to combat impunity $(2005)^{26}$. In any event, the enforced disappearances in the 1970 s drove to pay more attention to the concept of the right to the truth (para. 8). Since then, the General Assembly has addressed issues related to it in numerous reports and resolutions like for example 3220 (XXIX), 33/173, 45/165, and 47/132, which refer to "the desire to know" as "a basic human need" (para. 12). The Commission has also referred to it (para. 16) ${ }^{27}$.

Van Boven (2010) also reminds that the Basic Principles and Guidelines on the Right to a Remedy and Reparation for Victims of Gross Violations of International Human Rights Law and Serious Violations of International Humanitarian Law (General Assembly, Resolution 60/147 of 16 December 2005) ${ }^{28}$ have included the search for the truth as a form of reparation to victims (principles 22 and 24).

The right to the truth has been recognized as well at the American and European regional level. According to the Report of the Inter-American Commission on Human

\footnotetext{
${ }^{25}$ Rights Study on the right to the truth (E/CN.4/2006/91 8 February 2006). Available on https://documentsdds-ny.un.org/doc/UNDOC/GEN/G06/106/56/PDF/G0610656.pdf?OpenElement

${ }^{26}$ Commission on Human Rights, 8 February 2005 (E/CN.4/2005/102/Add.1)

${ }^{27}$ Other NU resolutions, reports and documents about truth and justice are available at https://www.ohchr. org/EN/Issues/TruthJusticeReparation/Pages/InternationalInstruments.aspx\#truth ${ }^{28}$ (A/60/509/Add.1).
} 
Rights $(2014)^{29}$, the legal framework of this right can be found in the Articles XVIII and XXIV of the American Declaration on the Rights and Duties of Man and Articles 8 and 25 of the American Convention on Human Rights, which are in some occasions connected (par. 69) to the right of access to information (Article IV of the American Declaration and Article 13 of the American Convention). Its development is considered as a response to the phenomenon of forced disappearance, as a common practice within Latin American dictatorships (para. $55 \mathrm{ff}$ ), and it implies the obligation to investigate and punish those responsible (para. $61 \mathrm{ff}$ ) and the obligation to establish the truth of what happened (para. $68 \mathrm{ff})$.

According to Navqi (2006) and López Guerra (2018), the European Court of Human Rights has inferred the right of the truth as part of several rights that are set forth in the European Convention of Human Right: the right to be free from torture or inhuman or degrading treatment or punishment (Article 3), the right to an effective remedy (Article 13), the right to an effective investigation and to be informed of the results (Article 10), the right to life (Article 2$)^{30}$ and the right to liberty and security (Article 7).

Regarding the contents of the right to the truth, the Office of the United Nations High Commissioner for Human Rights (2006: par. 38) considers that it implies to seek and obtain information on "the causes leading to the person's victimization; the causes and conditions pertaining to the gross violations of international human rights law and serious violations of international humanitarian law; the progress and results of the investigation; the circumstances and reasons for the perpetration of crimes under international law and gross human rights violations; the circumstances in which violations took place; in the event of death, missing or enforced disappearance, the fate and whereabouts of the victims; and the identity of perpetrators". Similarly, the Inter-American Commission (2014: par. 70) considers the following contents: "to know the truth about the events that led to serious violations of human rights, and the right to know the identity of those who played a role in those violations (...) and, depending on the circumstances of each case, to guarantee access to the information available in State facilities and files concerning serious human rights violations" 31 .

Finally, and taking into account the entitlement to the right to the truth, it is alleged to have two dimensions in the International and American framework: individual

\footnotetext{
${ }^{29}$ The Right to Truth in the Americas (OEA/Ser.L/V/II.152 Doc. 213 August 2014).

${ }^{30}$ According to Naqvi (2006: 257), this is displayed in several judgments like for example, Judgment of 25 May 1998, Kurt v. Turkey, Application No. 24276/94; Judgment of 14 November 2000, Tas v. Turkey, Application No. 24396/94; Judgment of 10 May 2001, Cyprus v. Turkey, Application No. 25781/94; Judgment of 10 May 2001, Cyprus v. Turkey, Application No. 25781/94, para. 136; Judgment of 18-121996, Aksoy v. Turkey, Application No. 21987/93; and Judgment of 28 March 2000, Kaya v. Turkey, Application No. 22535/93). This also applies where non-state parties may be involved: Tanrikulu v. Turkey, 1999-IV Eur. Ct. H.R. 459 (1999).

${ }^{31}$ The Inter-American Commission (2014: 36) has summarized some important Judgments that have determined these contents, since I/A Court H.R., Case of Velásquez Rodríguez v. Honduras. Judgment of July 29, 1988. Series C No. 4, para. 181. See also Bernales Rojas 2016: 279-281.
} 
(referred to the victims and their families) and social (all society) ${ }^{32}$, but in the European framework, the social dimension only implies the right to be informed (López Guerra: 25-29).

\subsection{The Tribunal of Inquiry as part of public inquiries}

The Tribunal of Inquiry is part of the tradition of British public inquiry and accountability in public life. It is vested with all the powers of the High Court. Although it meets in public, it does not exercise its function in the same way as the High Court exercises its criminal or civil jurisdiction in the adversarial system. In such cases, the opposing parties present the evidence, according to which the courts make a final decision. On the contrary, the Tribunal of Inquiry's duty is to find evidence of what happened, to search for the truth. For this reason, the Tribunal does not accuse individuals or institutions.

According to The Public Administration Committee Publications of the UK Parliament (2005), Parliament has traditionally made such inquiries into government failures, but ensuring independence from political parties was not easy. However, after the impact of the Committee's investigations on the Marconi Wireless and Telegraph Company Agreement (which Chesterton said "had concluded [in 1913] as such affairs always conclude in modern England, with a formal verdict and a whitewashing committee"), the Tribunal of Inquiry (Evidence) Act $1921^{33}$ was passed. Many of those tribunals were now chaired by judges, who were considered more independent than members of Parliament. This Act was in force until the Inquiries Act 2005 was passed $^{34}$.

The search for truth is so important that Act 1921 imposed no limitations on the Tribunal's control over its procedure, deadline and rules of evidence. It also operates under the inquisitorial approach in which truth is the fundamental goal, and it is the members of the Tribunal and not those from the parties who are responsible for finding it (Walsh, 1997). This was very well explained by Lord Saville (1998) during his Opening Statement of the second Bloody Sunday inquiry: "An Inquiry like the present Inquiry is quite different. Here the Tribunal takes the initiative in trying to ascertain the truth. Unlike an adversarial contest, it is for the Tribunal to seek all the relevant material. Its task is not to decide the matter in favour of one party or side or another. Indeed, from the point of view of the Tribunal, there are no parties or sides. There will, of course, be those who have material evidence to give or who have a legitimate interest in challenging such evidence, but the Tribunal will not treat them as sides or parties in an adversarial contest, but rather as a means of seeking out the truth". About the first Tribunal of Inquiry, its Chair, Lord Widegery (1972), said in his report: “(...) The Inquiry was essentially a fact-

\footnotetext{
${ }^{32}$ See the Inter-American Commission (2014: para. 70 and 71) and the Office of the United Nations High Commissioner for Human Rights (2006: para. 35 and 36).

${ }^{33}$ Available at http://www.legislation.gov.uk/ukpga/Geo5/11-12/7/section/1/enacted (Last retrieved 19/02/2020).

${ }^{34}$ Available at http://www.legislation.gov.uk/ukpga/2005/12/contents (Last retrieved 19/02/2020).
} 
finding exercise (...) The Bloody Sunday first Tribunal was not concerned with making moral judgments; its task was to try and form an objective view of the events".

In other words, there is no litigation neither plaintiff nor defendant, neither prosecutor nor accused (Blom-Cooper 2019). Sir Ian Kennedy, Chair of the Bristol Royal Infirmary Inquiry (1998-2001), summarised the functions that the inquiry had regularly accomplished under the Act 1921: "the recognition and identification of different, genuine perceptions of the truth; learning; healing; catharsis; prescribing; and accountability" 35 .

The "six cardinal principles" to be applied to the procedure of these tribunals were set out by Lord Salmond (1966, p. 17-18) in the report on these tribunals that he presented to Parliament ${ }^{36}$ :

1. "Before any person becomes involved in an inquiry, the tribunal must be satisfied that there are circumstances which affect them and which the tribunal proposes to investigate.

2. Before any person who is involved in an inquiry is called as a witness, they should be informed of any allegations made against them and the substance of the evidence in support of them.

3. They should be given an adequate opportunity to prepare their case and of being assisted by legal advisers and their legal expenses should normally be met out of public funds.

4. They should have the opportunity of being examined by their own solicitor or counsel and of stating their case in public at the inquiry.

5. Any material witnesses they wish to call at the inquiry should, if reasonably practicable, be heard.

6. They should have the opportunity of testing by cross-examination conducted by their own solicitor or counsel any evidence which may affect them".

These principles were not statutorily enforceable, and yet they were adopted. According to Blom-Cooper (2019), these principles "carried strong overtones of adversarial litigation", as Sir Richard Scott (Lord Justice of Appeal) had already stated in his Report of the Inquiry into the Export of Defence Equipment and Dual-Use Goods to Iraq and Related Prosecutions (1996). The reason for this was the presence of either a cross-examination or lawyers representing their clients' interests, which made Tribunals of Inquiries turn into lis. On the other hand, Lord Salmond (1966, p. 29) had made another recommendation that emphasised the perception that the Tribunal of inquiries is sliding to the judiciary: the Tribunal should be chaired by "a judge of high standing".

\footnotetext{
${ }^{35}$ See Purdue (2009: 952).

${ }^{36}$ Lord Salmond proposed them after the critics that Lord Denning's inquiry into the Profumo affair (1963) made arise.
} 
A strong legalism can be detected within the perception of a Tribunal of Inquiry. According to Judith Shklar ${ }^{37}$ : first, judges are more reliable than politicians because the former are considered to be acting under the law, while the latter are considered to be acting under sectarian political ideologies; second, the law is thought to be neutral and objective, while politics seem uncontrolled; third, the law aims for justice, while politics for expediency. For these reasons, the law and the judges are considered "intrinsically virtuous" and, thus, superior to politics.

In order to statutorily clarify the method of the Tribunal of Inquiry, ensure the inquisitorial approach, and move away from the adversarial system and the gravity field of the judiciary, the Inquiries Act 2005 was passed. It included, according to Blom-Cooper (2019, conclusions), two crucial reforms: "the establishment of a commission of inquiry that determines how and why the event concerned happened; and does not duplicate the finding of culpability of any individuals which is the remit of established courts of law. Second, the 2005 Act adopted the changed practice of investigation without any right of the witness to be alerted to potential criticism before giving evidence".

\section{Legal culture and Bloody Sunday Tribunals of Inquiry}

\subsection{Context}

Truth is a fundamental claim of the gender, racial or national groups that have suffered severe violations of their rights, as in Northern Ireland (Lawther, 2014; McEvoy, 2013; and Campbell \& Ní Aoláin, 2002). Considering Teitel's classification of transitional justice, Bloody Sunday Tribunals of inquiry showed the evolution of transitional justice from the second to the third phase within European territory, the results of which have impacted the global notion and current practice of transitional justice. In any case, the transitional justice system does not replace the adversarial criminal justice system, and families and human rights organizations are still waiting for formal accusations of murder or manslaughter against the soldiers and officers involved in the Bloody Sunday shootings ${ }^{38}$. Nevertheless, the truth about how and why it happened-which is what a Tribunal of Inquiry is supposed to achieve - remains as important as determining public and individual accountability for it. As Ulpiano once stated, justice is "the firm and continuous will to give each one his own". Establishing the truth is, therefore, the first step towards it, and this objective will be a shared claim among many cultural expressions surrounding the Bloody Sunday inquiries.

The two Bloody Sunday Tribunals of Inquiry were settled under the Act 1921. According to the Act, this occurs on "rare occasions", which explains its exceptional nature. A Tribunal of Inquiry had to be set up, according to Lord Salmond, Chair of the Royal Commission on Tribunals of Inquiry (1966, p. 16), "when crises of public

\footnotetext{
${ }^{37}$ Quoted by Blom-Cooper 2019, conclusions.

${ }^{38} \mathrm{At}$ the moment, only one soldier is going to be charged, but none of the officers. https://www.theguardian. com/uk-news/2019/mar/14/bloody-sunday-trial-will-test-limits-justice-northern-ireland (Last retrieved 09/03/2020).
} 
confidence occur, the evil, if it exists, shall be exposed so that it may be rooted out; or if it does not exist, the public shall be satisfied that in reality there is no substance in the prevalent rumours and suspicions by which they have been disturbed". This crisis is "about the alleged misconduct of ministers or other public servants" (Royal Commission on Tribunals of Inquiry, 1966, p. 10) and, certainly, the Bloody Sunday events constituted one of those rare occasions: it was the first time that the British government publicly applied such violence during a peaceful march (Campbell, 2013).

Although the Tribunals of Inquiries are not courts and the procedures within them are not trials under the adversarial system, they have been acting similarly, which was particularly evident in the Bloody Sunday inquiries. It seems that the presence of judges and certain procedural principles brought the Tribunal of Inquiries closer to courts and trials. If, as in the following pages, trials (understood within its broad sense) can be considered important tools for maintaining and transmitting legal culture while contributing to binding the system together ${ }^{39}$, it was clear that the Widgery Tribunal and its report did not contribute to that. Instead, they fuelled the conflict in Northern Ireland by exposing the futility of peaceful civil rights marches against internment and peaceful political associations. The result was that people preferred the IRA's solutions over constitutional politics and law (Campbell 2013). This was the situation that Saville Tribunal should resolve.

With these points in mind, the following pages will focus on the legal culture in the two Bloody Sunday Tribunals of Inquiry, as well as the importance of establishing the truth as an essential part of justice, revealing different ways and features throughout History. Legal culture expressions must be understood within a remarkable amount of high, popular, commercial or minority legal culture expressions that also include complaints, protest and resistance against the conflict in Northern Ireland. They refer to the Independence of the Republic of Ireland, the conflict in Northern Ireland, The Troubles and, even more specifically, the Bloody Sunday events ${ }^{40}$.

Studies have been carried out all of them within the scope of cultural theory, media studies, visual arts, and the emerging field of social memory studies ${ }^{41}$. Regarding Bloody Sunday in particular, they list different types of cultural expressions such as films, dramas, poetry, visual arts like Willie Doherty's work or the murals of Bogside Artist (the brothers Tom and William Kelly, and Kevin Hasson), among others. On the other hand, a list of

\footnotetext{
${ }^{39}$ This idea is defended by Friedman, 1969 and Brunner 2003, as can be seen infra. It is taken as a central premise in this article.

${ }^{40}$ In any event, talking about the "Irish culture" is very complicated, according to the studies about these cultural expressions on the conflict in Northern Ireland. It can push us to a metaphysical idea of nation frequently rooted in hegemonic visions of it. However, it drives to omit the plurality and richness of individual and social points of view on it and to fall often in unilateral hegemonic visions of the history of one community, pretending to be the standard or universal face to other visions. This idea of national culture is rejected, for example, in Gillespie 2008 regarding Irish cinema and the Irish-themed films.

${ }^{41}$ See among others Gleitman (2001), Herron and Lynch (2007), Campbell and Herron (2008), Gillespie (2008: 212 ff), Conway 2010, Moi (2011), Pötzsh (2011), Clark (2012).
} 
TV programmes about The Troubles and Bloody Sunday is available at CAIN ${ }^{42}$. Margo Harkin's TV documentary Bloody Sunday - A Derry Diary (2010 final version) can be considered part of them.

Even pop-music echoed the event-see John Lennon and Yoko Ono's Sunday Bloody Sunday (1972), from the album Some time in New York City (1972). They criticized the internments and shootings during the march of $30^{\text {th }}$ January 1972. Lennon's album included one more song on the internment, The Luck of the Irish, which was inspired by a civil march in London (1971) he had attended. However, Lennon thought that a new song denouncing the Bloody Sunday events was necessary. Bloody Sunday also inspired Paul and Linda McCartney to write Give Ireland Back to the Irish (1972) ${ }^{43}$. Sunday Bloody Sunday is also the title of a U2's song, in the album War (1983). The lyrics approach the end of the violence in Northern Ireland, and U2 members always stated that "this is not a rebel song". Still, U2's song is played at the end of the film Bloody Sunday by Greengrass, which was released at the Sundance Festival in 2002. It was the same year that Sunday, by MacDougall and McGovern, was also released.

Both films are seen as two memories-making movies intended to search for the truth, although their perspective on the events is different (Pötzsch, 2011, pp. 211-213). Bloody Sunday was mainly inspired by Mullan's book Eyewitness Bloody Sunday (1997) ${ }^{44}$. This work focuses on the events of $30^{\text {th }}$ of January and coincides with the Widgery findings ${ }^{45}$, endorsing all responsibility for Bloody Sunday to the Parachute Regiment and exempting political and military leaders. On the contrary, Sunday comes to the opposite conclusion. The directors went further, also addressing the years before Bloody Sunday by conducting a thorough investigation over three years. The research allowed them to understand Bloody Sunday within a wider historical context ${ }^{46}$, and to conclude that high political and military levels were involved in the military operation. As a cover-up, the Widgery Tribunal was thought to have denied justice to the victims and their families, which fuelled the conflict in Northern Ireland during the following years (Pötzsh 2011, pp. 215-218) ${ }^{47}$.

\footnotetext{
${ }^{42}$ Available at https://cain.ulster.ac.uk/othelem/media/tv10yrs.htm CAIN has also compiled a list of films on the conflict in Northern Ireland, including The Troubles and Bloody Sunday. Available at https://cain. ulster.ac.uk/images/cinema/nimovies.htm (Last retrieved 09/03/2020). The list also features films covering the Guilford Four (Sheridan's In the name of the father, 1993) and the Birmingham Six (Beckham's The Investigation: Inside a Terrorist Bombing, 1990). Both are related to their corresponding trials too.

${ }^{43}$ It was released as a single and recorded by the new McCartney's band, The Wings. It was considered proIRA and banned in the UK.

${ }^{44}$ Mullan was himself an eyewitness of Bloody Sunday massacre; he was 15 years old.

${ }^{45}$ According to Pötzsh (2011, p 214): "The killings were entirely unjustified (...) were carried out by an elite army unit out of control that bears sole responsibility for the fateful events. The soldiers lied about their conduct, yet without endorsement by military command or state authorities. None of the dead and wounded were armed. Even though the IRA did fire some shots that day, these shots did not influence the course of events in any way (...) The killings exacerbated the conflict (...)".

${ }^{46} \mathrm{It}$ is interesting to underline that most of the scenes were filmed in the areas and streets in Derry where Bloody Sunday happened.

${ }^{47}$ Campbell (2013) remembers that 1972 was the bloodiest year in a thirty-year struggle: 445 people were killed from February till December.
} 
Now that the context is clear, the expressions of the legal culture revolving around the Bloody Sunday Tribunals of Inquiry will be discussed below. These expressions were mainly reports, marches and demonstrations, but also in poems and even theatre plays. They came from national and international civil rights organizations, political activists, Bloody Sunday' victims and their families, people who attended the march in Derry on 30th January, as well as journalists, legal scholars or scientists, legal practitioners and legislators. They all placed truth as the main content of justice, and judges as the best positioned to establish the truth. Although they shared this starting point, their objectives and results differed.

\subsection{Trauma, anger and disappointment: Legal culture on Widgery inquiries during the 70s and 80s}

As mentioned above, the Widgery Tribunal and its Report brought deceit and, thus, profound frustration. Many people who attended the march on $30^{\text {th }}$ January 1972 and the Human Rights Association were unhappy with the Widgery Report, and the families of the injured and dead felt humiliated and offended as well (McCann 2006). However, they were not only in moral pain or trauma ${ }^{48}$, but also had to deal with being considered terrorists ${ }^{49}$.

One of the earliest reactions to the Widgery Report was the document elaborated by the Civil Rights Movement "to tell the world, through the eyes of Derry citizens, what happened in their city on Sunday $30^{\text {th }}$ January 1972" (1972). This document can be seen as an example of the counter-hegemonic legal culture at that time since it represented the response of subordinate groups (ethnic-nationalist or gender groups like black people and women) against the legal culture of dominant groups (male, white, colonialist). However, they were connected to the international civil rights movement rather than to specific nationalist movements. This document stated:

"The establishment of the Widgery Inquiry was meant to inhibit publication of eyewitness accounts and comment, shield those responsible and hide from the world descriptions of the terrible slaughter of innocent defenceless people. In speeches announcing the establishment of the Inquiry both $\mathrm{Mr}$. Reginald Maudling, the British Home Secretary, and Mr. Edward Heath, the British Prime Minister, publicly condoned the action of the British Army.

This pamphlet aims at telling the world, through the eyes of Derry citizens, what happened to thirteen of their number on Derry's Bloody Sunday”.

There were strong suspicions that Widgery Tribunal was biased in order to avoid criticism about the violence that the British Government applied to maintain its dominance in Northern Ireland.

A book published by the photojournalist Grimaldi $(1972,1998)$ was also beneficial to show these biases. Grimaldi witnessed the events, and the photos that he and other

\footnotetext{
${ }^{48}$ The deep trauma can also be explained from the violent and discriminatory environment where those people lived. About that, see Hayes and Campbell 2005.

${ }^{49}$ See the families' testimonies collected by Campbell 2013.
} 
photojournalists took were essential to denounce Widgery's incomplete and biased inquiry, as noted by Barcat (2014). These works can be seen as part of non-lawyerly legal culture that relied on the methods and tools provided by mass media workers, rather than those provided by lawyerly legal culture.

During the first years after Bloody Sunday, other interesting expressions of this external legal culture emerged, revolving around those events. They also originated poetry or theatre. Among several poems on Bloody Sunday ${ }^{50}$, a noted case in point is Thomas Kinsella's Butcher's Dozen: A Lesson for the Octave of Widgery (1979) ${ }^{51}$, which is the one most closely related to the Widgery Inquiry and Report. The title is a play on words between the popular idiom "a baker's dozen", which actually means 13 [it is said that during the Middle Ages bakers first started to add an extra thirteenth loaf of bread to ensure the correct weight by law ${ }^{52}$ ] while making a reference to the 13 people killed by the Parachute Regiment [making a carnage, as if they were butchers] during Bloody Sunday. The poem is "a pamphlet" written "in response to the Report of the Widgery Tribunal... [i]n the white heat of anger", as Kinsella (Dublin 1928) remarked. The poem satirically refers to the Widgery Tribunal and Report ("a great insult"), which exonerated those responsible for the shootings ${ }^{53}$.

The interesting point for our analysis is that Kinsella makes the dead tell their story in court: according to the Widgery Report, the victim Gerald Donaghy was found with nail bombs in his pockets. However, in Kinsella's poem, Donaghy resurrects to defend himself against this false accusation: "When a bullet stopped my breath/A doctor sought the cause of death. /He upped my shirt, undid my fly/Twice he moved my limbs awry, / And notice nothing. By and by/ A soldier, with his sharper eye,/Beheld the four elusive rockets/Stuffed in my coat and trouser pockets./Yes, they must be strict with us, /Even in death so treacherous!". Although Widgery blocked the testimony of many important Bloody Sunday witnesses, Kinsella was calling "to the stand" the impossible witnesses, the dead, to reveal the hidden truth that Widgery did not allow to come to light.

\footnotetext{
${ }^{50}$ As manifestations of poetry on specific Bloody Sunday events we have several poems: The road to Derry, by Seamus Heaney, written like a song after the funeral of the 13 dead people during Bloody Sunday but not published until 1997, in Derry Journal, in commemoration of $25^{\text {th }}$ anniversary of that [available at https:// issuu.com/derryjournal/docs/savillereport/28]. Heaney defended in his essay Place and Displacement that "poets did bear a "political responsibility" and that form was a powerful way of fulfilling this responsibility" (quoted in Clark, 2012, p. 285). It is also Derek Mahon's Derry Morning (1982); Paul Muldoon's The Year of the Sloes, for Ishi, a poem about Bloody Sunday but where Muldoon talks about the last tribe of Californian Indians; Seamus Deane's After Derry, 30 ${ }^{\text {th }}$ January 1972, written in 1972 and published in 1988; Gerry Dorrity's One Sunday or I remember, by Sharon Meenan and Killian Mullan's, among others. Many of these poems are available at http://www.troublesarchive.com/artforms/poetry/piece/. A wider selection of poetry about Bloody Sunday must be found on Campbell and Herron, 2008.

${ }^{51}$ Available at https:/cain.ulster.ac.uk/events/bsunday/kinsella.htm and http://www.troublesarchive.com/ artforms/poetry/piece/butchers-dozen-a-lesson-for-the-octave-of-widgery This poem was published firstly in 1972, in Dublin.

${ }^{52}$ This is the most accepted explanation about the origin of this expression, according to Encyclopaedia Britannica. Available at https://www.britannica.com/story/why-is-a-bakers-dozen-13

${ }^{53}$ Quoted in Clark, 2012, p. 379.
} 
Regarding its content, the poem accuses Lord Justice Widgery of not doing his job correctly by siding with the British army and then leaving the other party - the victims without their chances to speak their truth. It is, therefore, the poet who helped them to do so. However, he delves into the improper adversarial approach of the inquiry. As for the form, by using a couplet, Kinsella ironically criticizes British rationality and order. As Clark (2012, p. 381) says, "Kinsella's use of couplet, whose high point came in the eighteenth century, mocks an Enlightenment sensibility that cherished the values of freedom, tolerance and order- virtues the British associate with the national character but which, Kinsella implies, have undermined by imperial greed. Thus the sense of order in the rhymes is ironic; Kinsella satirizes the Tribunal's attempt to bring order to an event that in reality is too complex for simple verdicts".

Similarly, the Widgery Tribunal and Report served to frame the play The Freedom of the City: A play in Two Acts, first performed in 1973 and written by Brian Friel (Knockmoyle, Northern Ireland, 1929 - Greencastle, Ireland, 2015) ${ }^{54}$. Russell (2013, p. 101) believes that the work contains a "balanced critic of both brutal British imperialism and violent myth-imbued Irish republicanism". Although Friel had taken part in the civil rights march on $30^{\text {th }}$ January in Derry, he was feeling increasingly disappointed by Irish nationalism ${ }^{55}$. Inspired by Bloody Sunday and subsequent research, Friel's play tells a story that starts in 1970. It does not uniquely recreate or criticise the Widgery Tribunal, but also tries to show and reflect on how "brute facts" are transformed "into myth" through the experience of three civil rights protesters - Lily, Skinner and Michael — that are eventually murdered during the march, as well as through "the extravagant distortions of those events conjured by various "witnesses"” (Gleitman, 2001: 94). Among these "witnesses" Friel included the participants in a tribunal investigating the three marchers' death. The writer wrote his play while the Widgery Tribunal was investigating the events and Widgery himself can be recognised in the Judge character, when he quotes real Widgery's words "a fact-finding exercise" to answer the question "Did the security forces initiate the shooting or did they merely reply to it?" However, Friel takes the findings beyond the Tribunal of Inquiry into a more comprehensive social investigation and discussion on recent Irish history.

\subsection{To set the truth: the Justice Campaign and other expressions of legal culture during the $1990 \mathrm{~s}$}

As mentioned above, one of the most important reasons for launching a second Inquiry was the impulse generated by the justice campaign and investigations promoted by the very victims and their families in order to "set the truth" (Campbell, 2013) and for the subsequent acquittal on terrorism charges. This initiative would serve to heal the "double injury" caused by the massacre and lies that the British authorities imposed on these events (Herron and Lynch 2007, p. 6). It also drew the world's attention to what

\footnotetext{
${ }^{54}$ Carthaginians, by McGuiness, also deals with Bloody Sunday but not directly with the Tribunal of Inquiry. ${ }^{55}$ According to Richard Rankin Russell (2013: 101), his father has served on the Derry Corporation as a Nationalist councillor.
} 
happened on $30^{\text {th }}$ January in the streets of Derry and the biased and unfair nature of the Widgery Tribunal and the resulting Report ${ }^{56}$. This justice campaign is a moving display of popular legal culture claiming truth as the main content of justice ${ }^{57}$. At the same time, it provided a peaceful and non-Sinn Féin-influenced announcement of the fact that Britain's dominant legal culture had lost its credibility and political legitimacy.

However, the justice campaign started and spread later, during the 1990s. Until then, the annual events in Derry (Conway 2010) commemorating the Bloody Sunday victims can also be found as a form of popular legal culture. The main goal of these events was to maintain their memories alive. NICRA organized the first memorial march in 1973, but they had lost social influence, so Sinn Féin organised the following commemorations until the end of the 1980s. However, many families of the victims were not happy with the presence of Sinn Féin and walked away from these commemorations. They also seemed to have got used to the injustice and trauma that come from being seen as families of terrorists (Campbell 2013). These tributes can be understood as part of the spontaneous popular legal culture to which Sinn Féin gave a political nuance of counter-hegemonic reaction against British dominance in Northern Ireland.

The justice campaign began when the families tried to take control of the Bloody Sunday commemorations. The first step in this direction was the Bloody Sunday Initiative (BSI), encouraged by some victims' families like Tony Doherty and political activists like Robin Perceval (born in Liverpool) or, later, Ewan McCann. McCann was in Bogside and witnessed the massacre. The first meeting was organized with the help of a paper written by Percival in collaboration with Doherty, The Bloody Sunday Trust (1989), addressing the ruling body of Derry Sinn Féin, and declared its intention to draw national and international attention on Bloody Sunday "as a justice issue" (Campbell 2013). In the end, they decided to name the new organization The Bloody Sunday Initiative (BSI).

The first decision of this new organization was to commission McCann to write a report on what happened during that fateful $30^{\text {th }}$ January. McCann researched and collected families and friends' interviews and memories. The book, entitled Bloody Sunday in Derry: What Really Happened, was published in 1992, coinciding with the $20^{\text {th }}$ anniversary. They also planned the 1990 anniversary as part of a weekend dedicated to human rights, but it turned out to be a terrible tragedy when the IRA bombed British army patrols during the march, killing one protester. Despite the shock, the BSI scheduled another weekend of events in 1991.

The events were entitled "Towards Justice". Interestingly, they planned different activities such as debates on women and inequality, Christians and oppression or censorship and a dramatization, as well as discussions "on knowing your rights when arrested or

\footnotetext{
${ }^{56}$ Including English people like Labor Party MP, Jeremy Corbyn, singers like Peter Gabriel, actors, among others. See Campbell, 2013.

${ }^{57}$ See once again the 4,29 minutes of Marko Hankin's Bloody Sunday -A Derry Diary, available at http:// www.besomproductions.co.uk/sunday.html Previously, the marchers have broken a big banner with the image of the front page of the Widgery Report.
} 
harassed on the streets". A turning point in the process of engaging families in a justice campaign came when the release of the Birmingham Six was broadcasted on TV, the six of them brimming with joy in front of the Central Criminal Court at Old Bailey (London). This event proved that justice campaigns could be successful. The context at that time illustrated a new pro-human rights era, especially in the UK, which contributed to bringing attention to the severe injustices committed against Northern Irish people and to the biased trials that resulted in charges of terrorism and many years of prison sentences. The bestknown cases were the Guilford Four and the Birmingham Six. Their release provided a new impulse to revive the public attention concerning the Bloody Sunday events and raise the possibility that the victims and their families were not terrorists.

The Bloody Sunday Justice Campaign (BSJC) was born in 1992 independent of the BSI, and had three specific demands: "the repudiation of Widgery and the institution of a new inquiry; a formal acknowledgement of innocence of all the victims; and the prosecution of those responsible for the death and injuries". Members added: "We welcome into membership anyone who supports our objectives irrespective of religion or political persuasion" (Campbell 2013).

Therefore, the Justice Campaign was not nationalistic, religious or politically biased but transversal, gathering all the people who were willing to share and work for those goals (Campbell 2013). On the other hand, it showed an idea of justice as truth that finally included the demand for the entire acquittal of the informal charges of terrorism of the Bloody Sunday victims and their families, as a result of the Widgery Report. This is precisely what Margo Harkin filmed in her documentary Bloody Sunday - A Derry Diary.

The increasing interest in what really happened on Bloody Sunday had led to other vital investigations that reflect the growing international legal culture of human rights and the connection between justice and truth. A case in point is the researches contained in the Report submitted to the Special Rapporteur on Summary and Arbitrary Executions by the British Irish Right Watch (1994) and, especially, in Walsh' study $(1997)^{58}$. A nongovernmental organization presented the former while a legal scholar presented the latter, but both pointed to the numerous biases in the Widgery Tribunal and Report. Among the situations that gave the Tribunal a biased image in favour of the Army, Walsh and the British Irish Rights Watch pointed out the composition of the Tribunal: Widgery was not only the Lord Chief Justice of England but also a former officer of the British Army. His military past might explain some of his statements (Report of the Tribunal 1972), such as: "Though I hesitate to make a positive finding against a deceased man, I was much impressed by Sergeant K's evidence". Another example would be when he (Widgery) explained why none of the soldiers got injured, even if they were cross-shooting: "The soldiers escaped injury by reasons of their superior field-craft and training".

\footnotetext{
${ }^{58}$ Along those years, many books or reports were published containing the investigations that private individuals like journalists, legal scholars and other kinds of researcher, families of the victims and human rights associations made. Among them: McCafferty (1989); McCann, Shields and Hannigang (1992); British Iris Right Watch (1994); McClean (1997); Mullan (1997); Walsh (1997, 2000), Pringle and Jacobson (2000); Hayes and Campbell (2005) (the book list is available at https://cain.ulster.ac.uk/events/bsunday/read.htm).
} 
Furthermore, the location where the sittings took place threw some doubts about its impartiality: the Tribunal did not sit in Derry but Coleraine, a mostly protestant town, because they believed that the lives of the soldiers involved in Bloody Sunday were in danger. For this reason, the soldiers remained anonymous, which did not apply to the other eyewitnesses - Catholics in a protestant town.

Many important eyewitnesses were also excluded, such as the members of the demonstration's security committee. According to the terms of reference (which focus only on "the streets of Londonderry on the afternoon of Sunday 30 January"), there were many restrictions related to the time or space of the findings. For example, only the shootings in the streets where the riots took place were considered. However, according to Lord Widgery, the Tribunal was "essentially a fact-finding exercise" on one particular question: "Who fired first?" To which Widgery responded: "I am entirely satisfied the first firing in the courtyard was directed at the soldiers".

It is also important to note that the Tribunal oddly collected from the evidence the police files of the deceased and some wounded in order to ascertain whether they had been convicted or suspected of firearms offences or paramilitary activities. It was eventually discovered that the Secretary of the Tribunal privately influenced the substance and presentation of the Tribunal's Report.

\subsection{Legal culture on the Saville Tribunal and Report: legalism, colonialism and new legitimation for British law}

The large social reaction and mobilisation analysed above proved that Widgery's findings and final report were biased, preventing a better understanding of the Bloody Sunday facts and reasons ${ }^{59}$. Twenty-six years later, in 1998, the British government admitted that the first Tribunal of Inquiry was not impartial, and set up a new Tribunal while recognising the influence of the protest and campaign asking for justice as truth. It happened when Tony Blair was Prime Minister of the United Kingdom. In his statement to the House of Commons - establishing a new Inquiry into Bloody Sunday on Thursday $29^{\text {th }}$ January 1998 - Mr Blair said $(1998)^{60}$ :

"Bloody Sunday was a tragic day for all concerned. We must all wish it had never happened. Our concern now is simply to establish the truth, and close this painful chapter once and for all.

Madam Speaker, members of the families of the victims (...), have conducted a long campaign to this end. I have heard some of their remarks over recent years and have been struck by their dignity. Most do not want recrimination. They do not want revenge. But they do want the truth. I believe that it is in the interests of everyone that the truth is established,

\footnotetext{
${ }^{59}$ Like on many other occasions, this Tribunal of Inquiry was also accused of whitewashing. ${ }^{60}$ Available at https://www.publications.parliament.uk/pa/cm199798/cmhansrd/vo980129/debtext/80129-06. htm and at https://cain.ulster.ac.uk/events/bsunday/tb29198.htm.
} 
and told. It is also the way forward to the necessary reconciliation which will be such an important part of building a secure future for the people of Northern Ireland. I ask all sides of the House to support our proposal for this Inquiry".

On this occasion, three members formed the second Tribunal, all of whom were judges: Lord Saville, an English Law Lord, and other two non-English judges from Commonwealth countries: Edward Somers, from New Zealand, and William Hoyt, from Canada $^{61}$. The second Tribunal of Inquiry took 12 years to complete its report ${ }^{62}$, which was compiled in 10 volumes. Compared to the Widgery Report, these new findings and report were clearly different in terms of extension and duration, contributing, thus, to highlighting again that the Widgery Tribunal and Report were biased. The Saville Report concluded that the Bloody Sunday victims were not the first to shoot ${ }^{63}$, meaning they were not terrorists.

Nevertheless, Blom-Cooper (2019) insists on that the Saville Tribunal also opted for an investigation of the facts in the form of a courtroom, just like the Widgery Tribunal, therefore making the Tribunal of Inquiry drift from investigation to litigation, from a truth commission to a court. As Saville was a lawyer, he could not prevent his lawful mindset from conducting the findings "lawyerly", and the legalism of adversarial procedures in criminal or civil trials was always present ${ }^{64}$. This fact implies the continuity of legalism within lawyers themselves as part of the legal culture even when it comes to this kind of tribunals, and also explains the long duration of the inquiry.

In any case, the Saville Inquiry also inspired cultural expressions in art, like Bloody Sunday. Scenes from the Saville Report, a play written by Mark Norton-Taylor (Buckinghamshire, UK, 1944). Although it mainly addresses the Saville Inquiry and its hearings, it also refers to the Widgery Inquiry at some points. The play was released in 2005, five years before the Saville's final report was published, and is considered a piece of verbatim theatre that follows the documentary theatre tradition. Also, it is written using real words and opinions (Lachman, 2007; Monks, 2013).

Trials are a common topic in verbatim theatre, which puts the theatrical procedure of law on the stage of a real theatre. The work Scenes from the Saville Report is part of a series of tribunal plays at the Tricycle Theater (London). In this case, Norton-Taylor

\footnotetext{
${ }^{61}$ CAIN: Events of Bloody Sunday-Chronology. Available on https://cain.ulster.ac.uk/events/bsunday/ chron.htm

${ }^{62}$ Available at http://webarchive.nationalarchives.gov.uk/20101103103930/http://report.bloody-sunday -inquiry.org/ [retrieved 17/03/2017]

${ }^{63}$ Saville report is available at https:/www.gov.uk/government/publications/report-of-the-bloody-sunday -inquiry

${ }^{64}$ “The elaborate preparation of written statements from potential witnesses, prepared by professional lawyers contracted out by the Inquiry team; the oral examination of witnesses by counsel to the Inquiry; crossexamination by counsel for interested parties (...); and constant legal submissions by counsel, resulting in applications to the courts for judicial review on two aspects of the Inquiry -the anonymity of soldier witness and the venue for the oral evidence of former soldier" (Blom-Cooper, 2019, conclusions)
} 
deals with a Tribunal of Inquiry. No matter how non-judiciary its nature was (especially when even its members used to not to care about it), in the end, it was just another way of showing law in action, besides getting it performed on stage.

In Norton-Taylor's Scenes from the Saville Report, there is also a peculiar encounter between the theatrical dimensions of tribunals - even if they are not part of the judiciaryand their display on stage. It is the theatre of law, in its strictest sense, that reinforces the legal education of the audience, beyond legal texts, institutions, and schools.

This piece was not the only verbatim work on the Saville Inquiry. McCann's interviews to victims' families who took part in those inquiries - collected in the book Bloody Sunday Inquiry-The Families Speak Out (2006) — inspired another documentary play entitled Heroes with Their Hands in the Air (2007), by Brady. The play allows to revoice and re-witness events like Bloody Sunday and brings them back to life ${ }^{65}$.

It seems that the Saville Report (2010) made the British Government recognise that soldiers and officers did not do well, and apologised. It also ended with Prime Minister Cameron publicly acknowledging the damage and humiliation that the British Government had unnecessarily inflicted on the victims of the Bloody Sunday and their families. On the other hand, Blair and Cameron's speeches gave the impression of a serious commitment to the rule of law and human rights in Northern Ireland, as a guarantee of justice, not only from a cultural perspective but also from its structural and substantive component. Thus, it was considered very necessary to restore people's confidence in the law. According to Walsh (2000, pp. 283-284):

"... Not only did the law fail to protect 28 innocent civilians from being shot dead or wounded by soldiers, but it also appears that the judicial process was deployed to cover up the full extent of the culpability of the soldiers and their military and political masters. It cannot be assumed, however, that Bloody Sunday was totally unique... Indeed at one level, Bloody Sunday might be considered as the most example of the rule of law being shamelessly prostituted in the service of the partisan security and narrow political interest of the state (...) In the light of the Good Friday Peace Agreement it would appear that effort are finally being made to lay the foundations for restoration of the rule of law and justice in Northern Ireland (...) The failure of law and justice encapsulated by Bloody Sunday is so fundamental in its nature and extend that it is seared into the collective consciousness of the nationalist community a fundamental distrust in the capacity of the law and judicial process to protect them against hostile force...".

\footnotetext{
${ }^{65}$ According to McCormick (2013/2014, p. 14), "The re-witnessing of events during Heroes allows the exposition of the audience's own memories that surround $30^{\text {th }}$ January 1972, and the events that followed. These memories, together with new ones produced through the experience of the documentary theatre, cannot help but increase the audience's involvement in the subject matter."
} 
Taking into account the second Inquiry and its results towards the truth, the recognition and the re-evaluation of the victims, their families and the Catholic Northern Irish community seem to have taken a good step towards a peace process that remains ${ }^{66}$. Nevertheless, the strong colonial and elitist British accent-British/English dominant culture-remaining in the Peace Process and the set-up of the Saville Inquiry has been criticised (Bentley, 2016): it was once again chaired by an English Lord Justice, ignoring that the British Government itself ordered the shootings. This fact eventually contaminated the neutrality and impartiality of the search for truth.

The sincerity of the Government's apologies has also been questioned, not only Cameron's (2010) but also Blair's (1998) during the Statement that established the second Inquiry ${ }^{67}$. They both contributed to maintaining the archetypal colonial discourse because it is another sign of the fantasy or idealisation of British military chivalry and heroism. Moreover, the colonialist aspect helps to maintain the Peace Process as a permanent, yet never-ending situation (a "process", indeed) where the never-ending conflict between two nationalist religious communities can now be managed without violence. Hence, the British Government imposes the idea that Northern Ireland is divided into two irreconcilable ethnic-national identities between which it is the arbitrator that brings understanding and peace. Northern Ireland seems to be inhabited by irrational uncivilised sectarian people who would kill each other and need someone to guide them ${ }^{68}$. But this depiction seems to be more imaginary than real, and the British state cannot be the arbitrator or ruler of anything related to the conflict in Northern Ireland, as it so much a part of it. Therefore, the second Inquiry and the Peace Process are still suspected of bias, condescending and manipulating colonialism (Bentley, 2016).

\section{Conclusions}

The events and inquiries around Bloody Sunday allow concluding that truth is an idea closely linked to justice and law and that it has an important social dimension. Likewise, justice as truth is strongly connected to judges' functions insofar as they are considered to be more neutral and impartial than politicians. This conception is especially accepted in cases of serious human rights violations. In any case, such ideas are part of legalism, which is also very widespread within the popular and high legal culture.

\footnotetext{
${ }^{66}$ The positive impact of the second Tribunal of Inquiry on the peace process has been analysed in Aiken 2015. The author assesses to what extent this inquiry has permitted to advance important aspects related to truth and justice. In any event, as said at the beginning of the article, the Bloody Sunday Tribunals of Inquiry did not mean the renouncement to the criminal justice system in order to charge those who shot the victims. See Walsh 2000, p. 284-312.

${ }^{67}$ It was clear that the goal was not to charge anyone of murder or something like that, as Mr Blair himself stated (1998): "Madam Speaker, let me make clear that the aim of the Inquiry is not to accuse individuals or institutions or invite fresh recriminations but to establish the truth about what happened on that day, so far as that can be achieved at 26 years' distance".

${ }^{68}$ The irrationality and less civilization within Irish or Scottish are part of racist and classist prejudices very rooted in English, who consider themselves civilized and morally superior and then legitimated to rule the others. They are present even in very well English defenders of human liberties like John Stuart Mill. However, Mill showed expressly his worry about the iniquities that English inflicted to Irish. See Mill, 1891, pp. 300-302.
} 
Legalism also makes truth commissions lean towards the judiciary and uses some essential principles of adversarial procedures when they are chaired by judges.

However, judges sometimes fail to do their job, especially during Widgery inquiries, which are suspected of being biased into justifying the British politics on Northern Ireland. Even the Saville inquiries did not escape from the suspicion of partiality, meaning a kind of undercover colonialism, which is not repressive now, and which accepts and regrets the terrible mistakes of the past. Despite its limitations, the Saville Tribunal and Report might never have happened without the varied social reactions against the Widgery Tribunal and Report. These reactions expressed, remembered and claimed an indelible social idea or value about justice as truth that authorities cannot forget as long as they want the law to be considered legitimate and, subsequently, respected.

In any case, legal culture does not only work as passive acceptance but also as formal or informal actions in the pursuit of justice, by using the legal means available and adapting them or forcing new ones.

\section{REFERENCES}

AIKEN, N. T. (2015) "The Bloody Sunday Inquiry: Transitional Justice and Postconflict Reconciliation in Northern Ireland, Journal of Human Rights, Volume 14, Issue 1, pp. 101-123.

ARISTODEMOU, M. (2014) Law, Psychoanalysis, Society. Taking the unconscious seriously. Routledge: London.

BARCAT, Ch. (2014) "Re-writing the Official Narrative of Bloody Sunday: The Role of Photographs. Revue LISA (Literature, history of Ideas, images and Societies of the English-Speaking world, vol. XII, No 3, pp. 1-17. Avalibale at https://journals. openedition.org/lisa/6050?lang=en. [last retrieved 17/02/2020].

BERNALES ROJAS, G. (2016) “El derecho a la verdad”. Estudios Constitucionales, Year $14, \mathrm{~N}^{\mathrm{o}} 2,2016$, pp. 263-304.

BENTLEY, T. (2016) Empires in Remorse : Narrative, postcolonialism and apologies for colonial atrocity, Routledge: New York.

BLAIR, T. (1998), Statement by Tony Blair, then British Prime Minister, establishing the new Inquiry, (29 January 1998). London: House of Commons. Available at https://www.publications.parliament.uk/pa/cm199798/cmhansrd/vo980129/ debtext/80129-06.htm and at https://cain.ulster.ac.uk/events/bsunday/tb29198. htm. [last retrieved 17/02/2020].

BLOM-COOPER, L. (2019) Public Inquiries. Wrong Route on Bloody Sunday. Hart Publishing.

BLOOM, H. (1995) El canon occidental. Barcelona: Anagrama.

BOBBIO, N. (1980) "Naturaleza y función de la filosofía del Derecho", in Bobbio, N. Contribución a la Teoría del Derecho. Valencia: Fernando Torres ed., pp. 91-101. 
British Irish Right Watch (1994) Submission to the United nations's Special Rapporteur On Summary And Arbitrary Executions. Available on http://cain.ulst.ac.uk/events/ bsunday/birw.htm [last retrieved 27/02/2020].

BRUNER, J. (1990) Acts of Meanings. Cambridge (Massachusetts)-London: Harvard University Press.

BRUNER, J. (1996) The Culture of Education. Cambridge (Massachusetts)-London: Harvard University Press.

BRUNER, J. (2003) Making Stories: Law, Literature, Life. Cambridge (Massachusetts)London: Harvard University Press.

BUENO, G. (2000) El mito de la cultura. Ensayo de una filosofía materialista de la cultura. Barcelona: Prensa Ibérica.

CAMERON, D. (2010) Statement by David Cameron, then British Prime Minister, following the publication of the report of the Bloody Sunday Inquiry, House of Commons, London, (Tuesday 15 June 2010). London: House of Commons. Available at https://cain.ulster.ac.uk/issues/politics/docs/pmo/dc150610.htm and at https://www.publications.parliament.uk/pa/cm199798/cmhansrd/vo980129/ debtext/80129-06.htm [last retrieved 17/02/2020].

CAMPBELL, C. \& NÍ AOLÁIN, F. (2002), "Local Meets Global: Transitional Justice in Northern Ireland", Fordham International Law Journal, Volume 26, Isse 4, pp. 871-892.

CAMPBELL, J. and HERRON, T. (eds.) (2008), Harrowing of the Heart the Poetry of Bloody Sunday. Derry: Guildhall Press.

CAMPBELL, J. (2013) Setting the truth Free. The Inside Story of the Bloody Sunday Justice Campaign. Liberties Press.

CLARK, H. (2012) "Befitting Emblems: The Early 1970s", in Breaton and Gillis (eds.), The Oxford Handbook of Modern Irish Poetry. Oxford: Oxford Unviersity Press.

Civil Rights Movement (1972) Massacre at Derry. Derry: Civil Rights Movement (available at https://cain.ulster.ac.uk/events/bsunday/mad.htm) [last retrieved $17 / 02 / 2020]$

Commission of Human Rights (2005) The updated set of principles for the protection and promotion of human rights through action to combat impunity, 8 February 2005 (E/CN. 4/2005/102(Add. 1).

CONWAY, B. (2010) Conmemoration and Bloody Sunday. Pathways of memory. Basingstoke-New York: Palgrave MacMillan.

FRIEDMAN, L. (1969) "Legal Culture and Social Development”, Law \& Society Review, Journal of the Law and Society Association, Vol. 4, No 1, pp. 29-44.

FRIEDMAN, L. (1977) Law and Society. An Introduction. Englewood Cliffs: Prentice Hall. 
FRIEDMAN, L. (1989) "Law, Lawyers, and Popular Culture", The Yale Law Journal, Vol. 98, No 8, Symposium: Popular Legal Culture (June, 1989), pp. 1579-1606.

FRIEDMAN, L. (1994) Total Justice. New York: Russell Sage Foundation.

FRIEL, Brian (1974) The Freedom of the City: A Play in two Acts. Samuel French.

GADAMER, G (1977) Verdad y método, Salamanca: Sígueme.

GILLESPIE, M. P. (2008) The Myth of an Irish Cinema: Apporaching Irish-Themed Films. Syracuse: Syracuse University Press.

GILROY, P. (1995) “British Cultural Studies and the Pitfalls of Identity” in Curran, Morley and Walkerdine (eds.). Cultural Studies and Communication. London-New DheliNew York-Syney: Bloomsbury.

GLEITMAN, C. (2001) "Negotiating Hostory, Negotiating Myth: Friel among His Contemporaries", in King, K. (ed.) Modern Dramatists: A Casebook of major British, Irish, American Playwrigts. New York-Oxford: Routledge.

GRIMALDI, F. $(1972,1998)$ Blood in the Street. Derry: Guildhall Press.

HAYES, P. and CAMPBELL, J. (2005), Bloody Sunday. Trauma, Pain and Politics. Pluto Press: London-Dublin-Ann Harbor MI.

HERRON, T and LYNCH, J. (2007), After the Bloody Sunday: Ethics, Representation, Justice, Cork University Press, Cork.

KINSELLA, Th. (1979) Butcher's Dozen: A Lesson for the Octave of Widgery. Dublin: Dolmen.

LACHMAN, M. (2007) "History or journalism: two narrative paradigms in Bloody Sunday Scenes from the Saville Inquiry by Richard Norton-Taylor", Studia Anglica Posnaniensia, 43, pp. 305-314.

LAWTHER, Ch. (2014) Truth, Denial and Transition. Northern Ireland and the Contested Past, New York: Routledge.

LEGAZ Y LACAMBRA, L. (1953) Filosofia de Derecho. Barcelona: Bosch.

LÓPEZ GUERRA, L. (2018) “El derecho a la verdad: ¿la emergencia de un nuevo derecho en la jurisprudencia del Tribunal Europeo de Derechos Humanos?", Anuario Iberoamericano de Justicia Constitucional, 22, pp. 11-30. Available at a https:// doi.org/10.18042/cepc/aijc.22.01 [retrieved 24/07/2020].

McCAFFERTY, N. (1989), Peggy Deery: A Derry Family at War. London: Virago.

McCANN, E., and SHIELS, M. (eds.) (1992) Bloody Sunday in Derry: What Really Happened. Dingle: Brandon Books.

McCANN, E. (ed.) (2006) The Bloody Sunday Inquiry: The Family Speak Out. London; Ann Arbor Mich: Pluto Press.

McCLEAN, R. (1997) The Road to Bloody Sunday. Derry: Guildhall Press. 
McCORMICK, S. (2013/2014) "Heroes with Their Hands in the Air: Memory and Commemoration in the Contemporary Documentary Theater", Kritica Kutura, 21/22.

McEVOY, K. (2013) The Trouble with Truth. Dealing with the Past in Northern Ireland. Willam Publishing.

MILL, J. S. (1891) Considerations on representative Government. London: Parker, Son and Burn, West Strand.

MOI, R. (2011) "In a gosthly pool of blood/ a crumpled phantom hugged the mud": Spectropoetic Presentations of Bloody Suanday and the crisis of Northern Ireland", in Karhio, A., Crosson, S., and Armstrong, Ch. I., Crisis and contemporary poetry. London: Palgrave MacMillan.

MONKS, A. (2013) “This Painful Chpater': Performing the Law in Bloody Sunday: Scenes from Saville Inquiry", Contemporary Theatre Review, volume 23, Issue 3.

MULLAN, D. (1997) Eyewitness Bloody Sunday. Dublin: Wolfhound.

NAQVI, Y. (2006) "The right to the truth in the International Law: fact or fiction?", International Review of the Red Cross, volume 88, Issue 862, June, pp. 24-273.

NEUMANN, P. (2003) Britain's Long War: British Strategy in the Northern Ireland Conflict 1969-98. Palgrave MacMillan, New York.

PÉREZ, C. (2006) "Derecho y literatura”, Isonomia, Issue 24, April.

PÖTZSH, H. (2011) "Renegotiating difficult past: Two Documentary dramas on Bloody Sunday, Derry 1972, Memory Studies. September 13.

PRINGLE, P. and JACOBSON, P. (2000) Those are real bullets, aren't they? London: Fourth Estate.

PURDUE, M. (2009) "Public Inquiries as a Part of Public Administration" in D. Feldman (ed.), English Public Law. $2^{\text {a }}$ edn. Oxford: Oxford University Press.

Report of the tribunal (1972) appointed to inquire into the events on Sunday, 30 January 1972, which led to loss of life in connection with the procession in Londonderry on that day by The Rt. Hon. Lord Widgery, O.B.E., T.D. H.L. 101, H.C. 220, April 1972, London, Her Majesty's Stationery Office, available at http://cain.ulst.ac.uk /hmso/widgery.htm [last retrieved 17/02/2020].

Report of the Bloody Sunday Inquiry (2010) The Rt Hon The Lord Saville of Newdigate (Chairman) The Hon William Hoyt OC The Hon John Toohey AC. 10 volumes. Ordered by the House of Commons to be printed on 15 June 2010. Available https://www.gov.uk/government/publications/report-of-the-bloody-sunday -inquiry [last retrieved 28/03/2020].

Royal Commission On Tribunals Of Inquiry (1966) Report of the Commission under the Chairmanship of the Rt. Hon. Lord Justice Salmond. Presented to Parliament by Command of Her Majesty, November, 1966, London, Her Majesty's Stationery Office.

RUSSELL, R. R. (2013) Modernity, Community and Place in Brian Friel's Drama. Syracuse. Syracuse University Press. 
SALGUERO SALGUERO, M. (2014) “La tarea crítica de la Filosofía jurídica en el espacio académico de la facultad de derecho", in JD Ruiz Resa (ed.) Política, economía y método en la investigación y aprendizaje del Derecho. Madrid: Dykinson, pp. 169-232.

SAVILLE, M. (1998) Opening Statement by Lord Saville. The Bloody Sunday Inquiry (Friday 3 April 1998). Available at https://cain.ulster.ac.uk/events/bsunday/ ms030498.htm. [last retrieved 15/02/2017].

STOREY, J. (2018) Cultural theory and popular culture: An introduction. Routledge.

TARUFFO, M. (2010) Simplemente la verdad. El juez y la construcción de los hechos. Madrid-Barcelona-Buenos Aires: Marcial Pons.

TEITEL, R. (2003) “Transitional Justice Genealogy”, Harvard Human Rights Journal, Volume 16, pp. 69-94.

The Inter-American Commission on Human Rights (2014) The Right to Truth in the Americas (OEA/Ser.L/V/II.152 Doc. 213 August 2014). Available at https://www .oas.org/en/iachr/reports/pdfs/Right-to-Truth-en.pdf [last retrieved 24/07/2020].

The Office of the United Nations High Commissioner for Human (2006) Rights Study on the right to the truth (E/CN.4/2006/91 8 February 2006). Available at https:// documents-dds-ny.un.org/doc/UNDOC/GEN/G06/106/56/PDF/G0610656. pdf?OpenElement [last retrieved 24/07/2020].

The Public Administration Committee Publications of the UK Parliament (2005) First Report. Available at https://publications.parliament.uk/pa/cm200405/cmselect/ cmpubadm/51/5105.htm [last retrieved 28/03/2020].

VAN BOVEN, Th. (2010) The United Nations Basic Principles and Guidelines on the Right to a Remedy and Reparation for Victims of Gross Violations of International Human Rights Law and Serious Violations of International Humanitarian Law. United Nations Audiovisual Library of International Law. Available at https:// legal.un.org/avl/pdf/ha/ga_60-147/ga_60-147_e.pdf [last retrieved 24/07/2020].

VAN KOPPEN, J.PENROD, STEVEND. (2003)“Adversarial or Inquisitorial?”, in Van Koppen, J. Penrod and Steven D. (eds.) Adversarial versus Inquisitorial Justice. Psychological Perspectives on Criminal Justice Systems, Springer, Boston, MA,pp. 1-19.

VYGOTSKII, L. (2010) Pensamiento y lenguaje. Barcelona: ed. Paidós.

WALSH, D. (1997) The Bloody Sunday Tribunal of Inquiry. A Resounding Defeat for Truth, Justice and the Rule of Law. Report for the Bloody Sunday, part 3, available at http://cain.ulst.ac.uk/events/bsunday/walsh.htm [last retrieved 15/02/2017].

WALSH, D. (2000) Bloody Sunday and the Rule of Law in Northern Ireland. PalgraveMacMillan UK.

WILLIAMS, R. (1983, 1991) Writing in Society. London: Verso.

Received: April 29 2020

Accepted: June $25^{\text {th }} 2020$ 